\title{
Retained intraorbital foreign body imaging!
}

\author{
Krishna Sindhu Nadella, Oshin Bansal
}

Oculoplasty, LV Prasad Eye Institute Bhubaneswar Campus, Bhubaneswar, Odisha, India

\section{Correspondence to} Dr Krishna Sindhu Nadella; krishnasindhu19@gmail.com Dr Oshin Bansal; oshin.hp7@gmail.com

Accepted 8 July 2020

\section{DESCRIPTION}

A 34-year-old deaf and mute male patient presented to our institute with chief problem of mass on the right eye (RE) upper lid and drooping of the right upper eyelid for 1 month. The trauma history could not be elicited as the attender was not aware of it and noticed only when the mass became large in size.

Visual acuity assessment was not possible in this case considering his mental acuity. Examination of the right eye showed a mass of $5 \times 5 \mathrm{~mm}$ in the upper lid associated with severe ptosis. Ocular movements were full and free in all directions (figure 1A). On slit lamp examination there was discharge and congestion of palpebral conjunctiva, but the rest of the anterior segment examination as well as fundus was normal (figure 1B).

A CT scan was reviewed and found to have a hyperdense linear mass suggestive of a foreign body contiguous with inflammatory changes in superior orbit (figure 2A). A metallic foreign body was hence suspected and the patient was planned for exploration and foreign body removal. Intraoperatively a single large wooden foreign body was noted embedded within orbital fat associated with granuloma. It was removed in toto and sent for microbiological assessment along with granulomatous tissue. The patient was then treated with

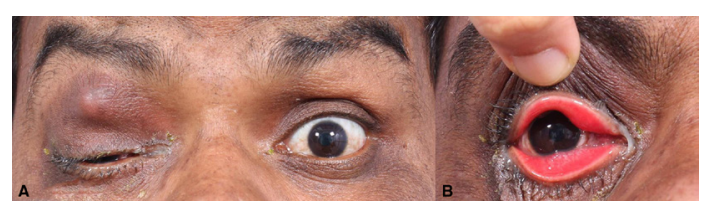

Figure 1 (A) Standard clinical photo showing the right eye (RE) $5 \times 5 \mathrm{~mm}$ mass on the upper eyelid along with severe ptosis. (B) clinical photo of RE showing matting of lashes and palpebral conjunctival congestion.
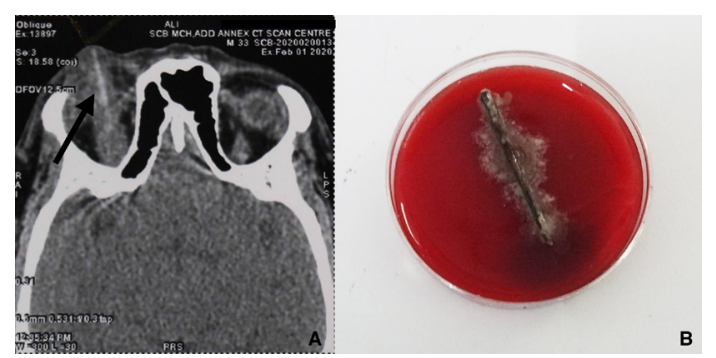

Figure 2 (A) CT scan of orbit in axial cut showing hyperdense linear mass suggestive foreign body contiguous with inflammatory changes. (B) Blood agar plate showing wooden foreign body along with surrounding growth (Pseudomonas aeruginosa and Bacillus sp).

\section{Patient's perspective}

I had been told that my brother had a foreign body that entered through the upper eyelid. As the foreign body is causing redness and swelling of the eye, it should be removed surgically.

\section{Learning points}

A hyperdense foreign body may not always be metallic.

- Wood can present as isodense, hypodense or hyperdense depending on the environment.

systemic cefuroxime based on antibiotic sensitivity (figure 2B).

In Scofield-Kaplan et al reported a similar case. Normally wooden foreign body detection on a CT scan is difficult. ${ }^{1}$ It appears isodense or hypodense and can mimic air or fat. Wood, being highly porous can imbibe fluid and then appear hyperdense on CT. The change in attenuation of wood depends on its local environment. Dry wood with high air content has low attenuation and mimics gas collection, and wood that has absorbed fluid gets organised and shows high attenuation. ${ }^{2}$ In our case, similarly a long standing retained wooden foreign body appears hyperdense on imaging.

To conclude, a long standing retained foreign body appearing hyperdense on imaging may not always be a metallic one. A wooden foreign body tends to change its imaging characteristics with time based on the surrounding environment.

Contributors OB: diagnosis and management, concept, design, manuscript writing and editing. KSN: literature search and review, data acquisition and analysis, manuscript writing and editing.

Funding The authors have not declared a specific grant for this research from any funding agency in the public, commercial or not-for-profit sectors.

Competing interests None declared.

Patient consent for publication Next of kin consent obtained. Provenance and peer review Not commissioned; externally peer reviewed.

\section{REFERENCES}

1 Fulcher TP, McNab AA, Sullivan TJ. Clinical features and management of intraorbital foreign bodies. Ophthalmology 2002;109:494-500.

2 Scofield-Kaplan SM, Weidman EK, Moonis G, et al. Orbital wooden foreign body manifesting as hyperdensity on computed tomography. $J$ of American Association for Pediatric Ophthalmology and Strabismus 2019;23:45-7. 
Copyright 2020 BMJ Publishing Group. All rights reserved. For permission to reuse any of this content visit https://www.bmj.com/company/products-services/rights-and-licensing/permissions/

BMJ Case Report Fellows may re-use this article for personal use and teaching without any further permission.

Become a Fellow of BMJ Case Reports today and you can:

- Submit as many cases as you like

Enjoy fast sympathetic peer review and rapid publication of accepted articles

Access all the published articles

Re-use any of the published material for personal use and teaching without further permission

Customer Service

If you have any further queries about your subscription, please contact our customer services team on +44 (0) 2071111105 or via email at support@bmj.com.

Visit casereports.bmj.com for more articles like this and to become a Fellow 